\title{
Influence of salt of different origin on the microbiological characteristics, histamine generation and volatile profile of salted anchovies (Engraulis encrasicolus L.)
}

\author{
Antonio Alfonzo a , Raimondo Gaglio a , Nicola Francesca ${ }^{a}{ }^{*}$, Marcella Barbera ${ }^{a}$, \\ Filippo Saiano ${ }^{a}$, Andrea Santulli ${ }^{b}$, Michele Matraxia ${ }^{a}$, Francesco Rallo ${ }^{c}$, \\ Giancarlo Moschetti ${ }^{\text {a }}$ \\ a Dipartimento Scienze Agrarie e Forestali, Università degli Studi di Palermo, Viale delle Scienze 4, 90128 Palermo, Italy \\ b Dipartimento Scienze della Terra e del Mare, Università degli Studi di Palermo, Via Archirafi 22, 90123 Palermo, Italy \\ c Agrichimica Laboratories, Via Sirtori 31, 91025 Marsala, Trapani province, Italy
}

\section{A R T I C L E I N F O}

\section{Article history:}

Received 28 November 2017

Received in revised form 2 May 2018

Accepted 5 May 2018

Available online 9 May 2018

\section{Keywords:}

Anchovies

Bacterial community

Histamine

Salt

VOC

\begin{abstract}
A B S T R A C T
The effect of six salts of different geographical areas on the quality of salted anchovies was evaluated. The crude salts were chemically characterized by determination of inorganic and volatile organic compounds (VOCs). Salted anchovies, corresponding to six experimental trials, were subjected to microbiological, chemical (including histamine content) and sensory analysis during the entire period of ripening (150 days). The salts were characterized by marked differences in terms of major cations and trace element amounts. Among the 27 VOCs detected, octadecane was the most abundant compound and the main differences of the salts were registered for alkanes and alcohols. During maturation, significant microbiological differences between the salts were found for the levels of total aerobic mesophilic microorganisms, lactic acid bacteria, Staphylococcaceae and Enterobacteriaceae counts. All salted anchovies contained histamine below the thresholds allowed by current regulations, but statistical differences were registered for the concentrations of the different trials. Consistent differences were also revealed for their sensory profiles, in particular concerning odour and taste and overall acceptability. Several differences were also detected for dryness, brown colour, putrid odour, rancid and raw blood taste sensory attributes. Especially the differences in the composition (chemical and VOC's) of the raw salts used for the production of salted anchovies has a significant effect on the sensory characteristics of the final product.
\end{abstract}

() 2018 Elsevier Ltd. All rights reserved.

\section{Introduction}

Salting is an ancient technology applied to preserve fishes (Hall, 1992). Once in contact with fish tissues, $\mathrm{NaCl}$ induces several physico-chemical changes (Hernandez-Herrero, Roig-Sagues, Lopez-Sabater, Rodriguez-Jerez, \& Mora-Ventura, 2002; Roldan, Barassi, \& Trucco, 1985; Shenderyuk \& Bykowski, 1990). Furthermore, in this condition, the selection of a microbial community occurs and their enzymatic activities affect the lipid and protein component of fish tissues (Czerner, Tomás, \& Yeannes, 2011; Hernández-Herrero, Roig-Sagués, López-Sabater, Rodríguez-Jerez, \& Mora-Ventura, 1999a) during the ripening process (duration

\footnotetext{
* Corresponding author.

E-mail address: nicola.francesca@unipa.it (N. Francesca).
}

3-6 months). This process determines changes in color, juiciness, texture, odor and flavor (Coppes, Pavlisko, \& Vecchi, 2002; Triqui \& Reineccius, 1995a). Marine salts used for salting of anchovies represent the natural habitat of several halophilic archaea (Moschetti et al., 2006). These agents inhabiting extreme environments might be of particular importance for the ripening of salted anchovies (Lee, 2013). Many studies investigated the ability of extremely halophilic archaea (EHA) strains to produce enzymes, in particular proteases, for food applications (Akolkar, Durai, \& Desai, 2010; Giménez, Studdert, Sánchez, \& De Castro, 2000; Izotova et al., 1983; Kamekura, Seno, Holmes, \& Dyall-Smith, 1992; Ryu, Kim, \& Dordick, 1994; Shi et al., 2006; Stepanov et al., 1992; Studdert, Seitz, Gil, Sanchez, \& de Castro, 2001; Vidyasagar, Prakash, \& Sreeramulu, 2006). Most of the proteases produced by EHA are extracellular serine proteases which retain their enzymatic 
capacity at high salt concentrations. With these regards, Akolkar et al. (2010) reported that the inoculum of Halobacterium sp. SP1 (a red-pink colour culture) into salted fishes shortened the period of ripening and improved the chemical composition (amino acids profile) and the flavour of the final products. Furthermore, Aponte, Blaiotta, Francesca, and Moschetti (2010) and Alfonzo et al. (2017b) clearly showed that the use of red-pink archaea halophilic strains applied as starters might improve significantly the safety and the sensory quality of salted anchovies (Engraulis encrasicolus).

Traditional production protocols of salted anchovies include the use of sea salt (Aponte et al., 2010). Sea salt is processed from seawater left in salt pans. The final product is obtained by crystallisation due to the combined effects of wind and sunlight (Gianguzza, Pellizzetti, \& Sammartano, 2002). Before crystallization, seawater circulates along a series of successive ponds increasing the level of salinity due to continuous water evaporation. Contact with the surrounding environment is a potential source of volatile compounds affecting sea salt composition (Silva, Coimbra, Barros, Marriott, \& Rocha, 2015). Recent studies have shown that the geographical area of origin influences the chemical composition of sea salts, especially the volatile organic fraction (Silva et al., 2015). Thus, some chemicals can be used as markers to identify univocally each salt type.

Several salt pans are present in Italy with Cervia, Marsala and Pula representing the most important area of sea salt production (Maffeis, 2013). In Europe, the sites of Andiran in France and Santa Pola in Spain are also important. Up to date, the safety and sensory characteristics of salted anchovies have been only associated to the quality of fresh fish and the technological processes applied for production (Lee, 2013), but the role of salt has not been investigated yet. For these reasons, this study, was performed to examine the influence of salt from different geographical origins on the physicochemical, microbiological and sensory characteristics of salted anchovies.

\section{Materials and methods}

\subsection{Collection, microbiological and chemical analysis of salt samples}

Five samples of sea salt and one of mine salt were collected from different European sites (Table 1). Mine salt was included for comparison. All samples were stored at room temperature in a glass vacuum dessicator before analysis of EHA, heterotrophic marine bacteria, lactic acid bacteria (LAB), Enterobacteriaceae and Staphylococcaceae.

EHA were investigated after enrichment in Halobacterium liquid medium (HLM) (Oren \& Litchfield, 1999). The enrichement procedure was conducted as reported by Moschetti et al. (2006) inoculating $10 \mathrm{~g}$ of each salt sample in 250 of HLM into $500 \mathrm{ml}$ volume conical flasks incubated under constant shaking (150 rpm) and lighting for two weeks at $44{ }^{\circ} \mathrm{C}$. Ten milliliters of each culture were subcultured in the same conditions three times. Finally, $100 \mu \mathrm{l}$ from each broth were spread on Halobacterium medium agar

Table 1

Salt samples used in this study.

\begin{tabular}{llll}
\hline Samples & Company & Geographical origin & Source \\
\hline CER & Salina di Cervia & Cervia (RA, Italy) & Salt pan \\
FRA & Danival & Andiran (France) & Salt pan \\
MAR & Sale Cucchiara S.R.L. & Marsala (TP, Italy) & Salt pan \\
SAR & Su Sali Sanpaolo2 & Pula (CA, Italy) & Salt pan \\
SPA & Natural park of Santa Pola & Santa Pola, Alicante (Spain) & Salt pan \\
MIN & Italkali S.P.A. & Petralia (PA, Italy) & Salt mine \\
\hline
\end{tabular}

(HMA) and incubated at $44^{\circ} \mathrm{C}$ for two weeks.

The other microbial groups were investigated after decimal serial dilutions in Ringer's solution (Sigma-Aldrich, Milan, Italy): heterotrophic marine bacteria on Difco ${ }^{\mathrm{TM}}$ Marine Agar 2216 (Becton Dickinson, Milan, Italy) incubated at $25^{\circ} \mathrm{C}$ for $72 \mathrm{~h}$; mesophilic LAB rods and cocci on de Man-Rogosa-Sharpe (MRS) agar and M17, respectively, incubated in anaerobiosis at $30^{\circ} \mathrm{C}$ for $48 \mathrm{~h}$; members of Enterobacteriaceae and Staphylococcaceae families were investigated as reported by Alfonzo et al. (2017a). Analyses were performed in triplicate. All media and the supplements were supplied from Oxoid (Milan, Italy).

The six salts were also analyzed for the composition of cations and anions. Thirty-five grams of each sample were mixed in highly purified water ( 18 milliohm $\mathrm{cm}-1$ water Form a mill-QRG Millipore ultra-pure water System) and brought to $1 \mathrm{~L}$. The cations $\mathrm{Na}^{+}, \mathrm{K}^{+}$, $\mathrm{Ca}^{+2}$ and $\mathrm{Mg}^{+2}$ were measured with an atomic absorption spectrometer Varian AA240 Fast (Kawashima \& Nishiyama, 1989). The major anions $\mathrm{Cl}^{-}$and $\mathrm{SO}_{4}^{-2}$ were determined by ion chromatography (Dionex ICS-1100 in chromatograph with Dionex IonPac AS9HC column) (Atkinson \& Bingman, 1997). The remaining elements, $\mathrm{Ba}, \mathrm{Be}, \mathrm{Cr}, \mathrm{Cu}, \mathrm{Mn}, \mathrm{Co}, \mathrm{Ni}, \mathrm{Cd}, \mathrm{Pb}, \mathrm{Zn}$ were measured by Inductively Coupled Plasma emission spectroscopy (ICP) (Atkinson \& Bingman, 1997).

\subsection{Production of experimental anchovies}

Fresh anchovies (40 kg) were purchased from a fish market located in Palermo (Italy) and transferred refrigerated (by a portable fridge) to the Laboratory of Fermented Food Preparation of University of Palermo. The anchovies were gutted and put in $3.5 \mathrm{~kg}$ jar containing $2.0 \mathrm{~kg}$ of anchovies and $1.0 \mathrm{~kg}$ of each salt for six experimental trials (CER, FRA, SAR, SPA, MAR and MIN). The production of salted anchovies was performed as described by Aponte et al., 2010. The ripening of salted anchovies was carried out at $20^{\circ} \mathrm{C}$ for $150 \mathrm{~d}$. Samples of salted anchovies (about $50 \mathrm{~g}$ ) were collected before (untreated anchovies, UA) and immediately after the addition of salt ( 0 day) and at 3, 6, 12, 24, 48, 96 and $150 \mathrm{~d}$ of ripening.

All productions of salted anchovies were carried out in triplicate (three jars per trial).

\subsection{Monitoring of microbial populations}

Samples of anchovies were suspended 1:10 (w/v) in Ringer's solution (Sigma-Aldrich, Milan, Italy), homogenized by a stomacher (BagMixer ${ }^{\mathbb{B}} 400$, Interscience, St Nom. France) for 4 min at the maximum speed and subjected to the serial decimal dilutions. Different microbial groups were enumerated: total aerobic mesophilic microorganisms on Plate Count Agar (PCA), incubated at $30^{\circ} \mathrm{C}$ for $72 \mathrm{~h}$; mesophilic cocci lactic acid bacteria (LAB) on M17 agar, incubated anaerobically at $30^{\circ} \mathrm{C}$ for $48 \mathrm{~h}$; mesophilic rod LAB on de Man-Rogosa-Sharpe (MRS) agar, incubated anaerobically at $30^{\circ} \mathrm{C}$ for $48 \mathrm{~h}$; Enterobacteriaceae on double-layer Violet Red Bile Glucose Agar (VRBGA), incubated at $37^{\circ} \mathrm{C}$ for $24 \mathrm{~h}$; total staphylococci on Baird Parker (BP) and coagulase positive staphylococci (CPS) on BP added with Rabbit Plasma Fibrinogen (RPF) supplement, incubated aerobically at $37^{\circ} \mathrm{C}$ for $48 \mathrm{~h}$ (APHA, 2015). For the enumeration of halophilic microbial populations, samples of anchovies were suspended $1: 10(\mathrm{w} / \mathrm{v})$ in a $25 \%(\mathrm{w} / \mathrm{v}) \mathrm{NaCl}$ solution (Alfonzo et al., 2017b; Aponte et al., 2010; Moschetti et al., 2006). The microbial suspensions were inoculated into Halobacterium medium (HMA) and the count was performed after incubation at $44^{\circ} \mathrm{C}$ for $15 \mathrm{~d}$ under constant lighting. All media and the supplements were purchased from Oxoid (Thermofisher, Basingstoke, UK). All microbiological analyses were performed in triplicate. 


\subsection{Histamine determination}

Histamine content was determined at $0,75,120$ and $150 \mathrm{~d}$ of ripening of salted anchovies by acid extraction and successive derivatization. The analysis was performed by modifying the methods reported by Eerola, Hinkkanen, Lindfors, and Hirvi (1992) and Moret and Conte (1996). Stock standard solutions (1000 mg/L) containing histamine dihydrochloride (Sigma-Aldrich) and 1,7diaminoheptane (as internal standard) were prepared by adding weighed amount of histamine in ultrapure water (Easypure II, Thermo). The standard solution was stored at $4{ }^{\circ} \mathrm{C}$ until use. Homogenized aliquots of $5 \mathrm{~g}$ of anchovies from each trial were added to $10 \mathrm{ml}$ of $\mathrm{HCl} 0.1 \mathrm{M}$ containing $100 \mathrm{mg} / \mathrm{L}$ of the internal standard and homogenized with an Ultra-Turrax system ( $\mathrm{T} 25$ basic IKA labortechnik, Staufen, Germany). The mixture was centrifuged at $4000 \mathrm{rpm}$ for $30 \mathrm{~min}$ at $4{ }^{\circ} \mathrm{C}$ and the supernatant was separated through $0.45 \mu \mathrm{m}$ filters (Sartorius, Italy). The solid residue was newly extracted as described above. The two acid extracts were mixed and diluted up to $25 \mathrm{ml}$ with $\mathrm{HCl} 0.1 \mathrm{M}$. Aliquots of $1 \mathrm{ml}$ from each acid extract were mixed with $0.5 \mathrm{ml}$ of saturated $\mathrm{NaHCO}_{3}$ solution and $1.0 \mathrm{ml}$ of dansyl chloride solution $(5 \mathrm{mg} / \mathrm{ml}$ in acetone) and kept in darkness for $1 \mathrm{~h}$ at $40^{\circ} \mathrm{C}$. The residual dansyl chloride was removed by adding $300 \mu \mathrm{l}$ of ammonia solution (30\%) and each sample was left to react for $15 \mathrm{~min}$ at room temperature protected from light. Each sample was extracted twice with $1 \mathrm{ml}$ of diethyl ether, the combined extracts were dried and the residue dissolved with $1 \mathrm{ml}$ of acetonitrile and then injected in HPLC. The analyses and quantification of dansylated histamine were carried out by an Agilent 1200 HPLC system equipped with a G1316A Thermostated Column Compartment and a G1315D DAD detector (Diode Array Detector) injecting $20 \mu \mathrm{l}$ of each sample. The peaks were integrated at $254 \mathrm{~nm}$. The separation was carried out using an Agilent Eclipse XDB-C18 column $(4.6 \times 150 \mathrm{~mm}, 5 \mu \mathrm{m})$. The mobile phases were ultrapure water (A) and acetonitrile (B) eluting under gradient condition with a flow rate of $1 \mathrm{ml} / \mathrm{min}$. The gradient elution program was as follows: $0-12 \mathrm{~min}, 50-80 \% \mathrm{~B}, 12-25 \mathrm{~min}, 80-100 \% \mathrm{~B}$, $25-30 \mathrm{~min} 100-50 \% \mathrm{~B}$. The peak were integrated at $254 \mathrm{~nm}$. An external calibration was obtained by analysing six standard solutions at different concentrations derivatized as described for the samples. All analyses were performed in triplicate.

\subsection{Determination of volatile organic compounds}

The analysis of volatile organic compounds (VOCs) was performed on all samples of salt and salted anchovies at the end of the ripening process $(150 \mathrm{~d}$ ) by HS-SPME (head space-solid phase micro extraction) combined with gas chromatography mass spectrometry (GC-MS). Five grams of each sample were placed in $250 \mathrm{ml}$ glass vials closed with a silicon septum and placed at $60.0^{\circ} \mathrm{C}$ overnight to reach the equilibrium. The divinylbenzene/carboxen/ polydimethylsiloxane (DVB/CAR/PDMS, $50 \mu \mathrm{m}$, Supelco) fibre was used to adsorb a wide range of compounds with different physicochemical properties. The selected SPME fibre was conditioned for $2 \mathrm{~h}$ at $250^{\circ} \mathrm{C}$ in the inlet of a gas chromatograph according to the manufacturer's recommendations. The SPME fibre was then manually inserted into the sample vial headspace for $60 \mathrm{~min}$ at $25^{\circ} \mathrm{C}$ and the SPME coated fibre with adsorbed marine salt volatile compounds was manually introduced into the GC injection port at $250^{\circ} \mathrm{C}$ and left to desorption for $5 \mathrm{~min}$. Chromatographic analyses were conducted on a GC-MS system comprising of a GC instrument (Agilent 6890), a mass selective detector (Agilent 5975c) and a fused silica capillary column Carbowax (30 m length, $0.25 \mathrm{~mm}$ internal diameter, and $0.25 \mu \mathrm{m}$ film thickness from Supelco). All analyses were performed using the splitless injection mode and a temperature of $250^{\circ} \mathrm{C}$. MS instrument was operated at $70 \mathrm{eV}$ in the
EI mode over the $\mathrm{m} / \mathrm{z}$ range $30-550$. Helium carrier gas at $1 \mathrm{ml} / \mathrm{min}$ and the temperature of the oven was programmed from 40 to $230^{\circ} \mathrm{C}$ at $4{ }^{\circ} \mathrm{C} / \mathrm{min}$ and then held isothermal for $40 \mathrm{~min}$; the transfer line were selected at $250^{\circ} \mathrm{C}$. Identification of compounds was achieved by comparing the fragmentation patterns of the experimental mass spectra with a commercial library (NIST05). The relative proportions of individual components are expressed as percent peak areas normalisation, with all relative response factors being taken as one. Three replicates of each sample were analyzed. Blank sample, corresponding to analysis of the coated fibre not submitted to any extraction procedure, were run between sets of three analyses. All measurements were made using at least three replicates for each sample aliquot.

\subsection{Sensory analysis}

The evaluation of the sensory profiles of the experimental salted anchovies was performed by a descriptive method according to ISO 5496:2006. The analyses were applied on samples at the end of ripening.

Ten judges were trained in preliminary sessions using different samples of commercial salted anchovies in order to develop a common vocabulary for the description of the sensory attributes of the experimental samples, as well as to familiarize them with scales and procedures. Each attribute was extensively described and explained to avoid any doubt about the relevant meaning. The descriptors related to aspect (color homogeneity, pink and brown), odour (salted anchovies, fresh fish, putrid and rancid), texture (compactness, gummy, dryness), taste (salted anchovies, bitter, salt, ham, raw blood, putrid, rancid) and overall enjoyment were included in the analyses. The anchovies were randomly evaluated by assigning a score between 1.00 (absence of descriptor sensation) and 9.00 (extremely intense) in individual booths under incandescent white light. Two panel replications were carried out per each sample.

\subsection{Statistical and explorative multivariate analyses}

ANOVA test was applied to identify significant differences among the microbial counts. The post-hoc Tukey's method was applied for pairwise comparison of microbial counts, histamine contents and sensory scores. Statistical significance was attributed to $\mathrm{p}<0.05$.

In addition, an explorative multivariate approach was employed to investigate relationships among data obtained from the different experimentations. The inorganic elements that characterize the different salts have been subjected to multivariate analysis by means of principal component analysis (PCA) in order to define the differences between the salts.

In order to graphically represent concentrations of VOCs, a heat map clustered analysis (HMCA), based on hierarchical dendrogram with heat map plot, was employed to represent the individual content values contained in the data matrix as colours. The relative values of VOC concentrations were depicted by color intensity from blue (lowest concentration) to red (highest concentration). Heat map analysis of the volatile levels was performed using the autoscaled data (Gaglio et al., 2017).

The correspondence analysis (CA) was employed to investigate relationships among samples. The input matrix used for CA consisted of results from sensorial profiles.

Statistical data processing and graphic construction were performed with the XLStat software version 2014.5.03 (Addinsoft, New York, USA) for excel. 


\section{Results and discussion}

\subsection{Microbiological counts}

The presence of EHA in salts was revealed only for CER, FRA, MAR samples at levels of 2.26, 2.05, $2.08 \mathrm{Log}$ CFU/g, respectively. All other microbial groups investigated (heterotrophic marine bacteria, LAB, Enterobacteriaceae and Staphylococcaceae) were absent. These results are not surprising because similar findings were reported by Antón et al. (2002) and Moschetti et al. (2006).

The anchovies before application of the salting process were positive for the presence of almost all microbial groups object of investigation with levels of 4.14, 3.39, 3.27, 3.02 and 3.18 Log CFU/g for total aerobic mesophilic microorganisms, mesophilic LAB cocci, mesophilic LAB rods, Enterobacteriaceae and staphylococci. Halophilic bacteria were not detected in UA. The evolution of the viable counts during ripening is reported in Fig. 1 and Fig. S1. Generally, species and strains diversity of microorganisms during salting of anchovies is mainly affected by $\mathrm{a}_{\mathrm{w}}$, salt concentration and $\mathrm{pH}$ changes (Alfonzo et al., 2017a; Campello, 1985; Hernández-Herrero, Roig-Sagués, López-Sabater, Rodriguez-Jerez, \& Mora-Ventura, 1999b; Villar, de Ruiz Holgado, Sanchez, Trucco, \& Oliver, 1985).

The count of total aerobic mesophilic microorganisms (Fig. 1a; Fig. S1a) during the ripening per all trials remained almost constant until the $30^{\text {th }}$ day. At 60 days, the levels of total aerobic mesophilic were found statistically different between experimental productions: FRA, MIN, SPA and CER, MAR and SAR. This trend was observed until 90 days. At the end of the maturation period, the highest values of total aerobic mesophilic (3.28 Log CFU/g) were obtained in MIN.

At day 0 , the level of populations of mesophilic coccus LAB (Fig. 1b) was comprised between 3.15 and $2.07 \mathrm{Log}$ CFU/g. The coccus LAB concentration in samples at 0 day decreased in CER (2.56 Log CFU/g), MAR (2.07 Log CFU/g) and SAR (2.73 Log CFU/g). During the ripening process in all trials the levels of coccus LAB also decreased (Fig. S1b; Fig.S1c). At 150 days for all trials, except MAR, microbial concentrations decreased of $1.5 \log$ cycles. Significant differences were recorded between MIN (1.66 Log CFU/g), SAR (1.11 Log CFU/g) and FRA (1.15 Log CFU/g). The dynamics of populations of rod LAB (Fig. 1c) showed a similar trend to the previous microbial group. At 60 days, regardless of the type of salt used, the levels of rod LAB were similar among trials, while at 90,120 and 150 days there were significant differences between FRA, MIN, SPA and CER, MAR, SAR.

With regards to Enterobacteriaceae (Fig. 1d; Fig. S1d), significant differences were found between the levels present in fresh anchovies, compared to salted anchovies at time zero. With the exception of the first 3 day, until 90 days the microbial concentrations were similar. At the end of the maturation period, Enterobacteriaceae levels were different, as observed in PCA and MRS.

Significant differences among trials were found for the levels of staphylococci (Fig. 1e; Fig. S1e). From day 30 onwards, trials MAR, SAR and CER showed a significant decrease of staphylococci cell densities until 1.3 Log CFU/g at day 150. Coagulase positive staphylococci were not detected.

Halophilic bacteria were detectable only from 30 to $60 \mathrm{~d}$ onwards with levels of about $1.2 \mathrm{Log}$ CFU/g for all trials until the end of manufacturing process (Fig. 1f; Fig S1f). No difference in terms of microbial concentrations was found in the different trials.

The levels of the microbial groups investigated in this study are comparable to those reported in literature (Alfonzo et al., 2017a; Aponte et al., 2010; Hernández-Herrero et al., 1999b). In the present study, a decrease of the microbial counts of total aerobic mesophilic microorganisms, LAB (cocci and rods), Enterobacteriaceae and Staphylococcaceae was observed in relation to the type of salt applied for the salting process. This trend was not followed by the halophilic populations, since the salty environment became selective for this microbial group (Alfonzo et al., 2017a; Aponte et al., 2010; Czerner \& Yeannes, 2014; Pons-Sanchez-Cascado et al., 2005).

\subsection{Concentration of histamine}

Histamine is an organic basic compound of microbial origin in salted anchovies (Hernández-Herrero, Roig-Sagues, RodríguezJerez, \& Mora-Ventura, 1999c). Salt-ripened anchovies are among the fermented foods responsible for intoxication by histamine, as well as by other biogenic amines (Alves et al., 2017; Simon Sarkadi, 2016; Wantke, Hemmer, Haglmüller, Götz, \& Jarisch, 1996). For this reason, histamine content was determined in all experimental trials during the entire period of ripening (Table 2). At the beginning of the process, the value of the histamine for all experimental productions was between 39.88 and $41.22 \mu \mathrm{g} / \mathrm{g}$ which is in agreement with the value reported for similar unprocessed products (Pons-Sanchez-Cascado, Veciana-Nogués, Bover-Cid, Marine-Font, \& Vidal-Carou, 2005). During ripening, the trial MIN showed the highest value of histamine that reached values of 40.09 and $38.69 \mu \mathrm{g} / \mathrm{g}$ at 75 and $120 \mathrm{~d}$, respectively. High levels of histamine were also found for the trials SPA and FRA both at 75 and $120 \mathrm{~d}$. At the end of process, the lowest concentrations of this chemical were detected for trials MAR $(19.45 \mu \mathrm{g} / \mathrm{g})$, CER $(22.38 \mu \mathrm{g} / \mathrm{g})$ and SAR $(23.45 \mu \mathrm{g} / \mathrm{g})$. On the other hand, trial MIN showed the highest level ( $34 \mu \mathrm{g} / \mathrm{g}$ ) at day 150 . However, during the ripening process, histamine values showed statistically significant reductions for all trials (Table S2).

The decrease of histamine concentration observed during the ripening process of salted anchovies may be caused by oxidative deamination process catalyzed by either histamine oxidase or histamine dehydrogenase (Hacisalihoglu, Jongejan, \& Duine, 1997; Kung et al., 2016; Martuscelli, Crudele, Gardini, \& Suzzi, 2000; Zaman et al., 2014). These enzymes are produced by various strain of species of LAB (Dapkevicius, Nout, Rombouts, Houben, \& Wymenga, 2000), some strain of species of Staphylococcaceae (Martuscelli et al., 2000; Zaman et al., 2014) and some strain of EHA that can prevent or reduce the accumulation of histamine in salted fish (Tapingkae, Tanasupawat, Parkin, Benjakul, \& Visessanguan, 2010).

Despite the significant statistically differences found among experimental samples, the concentrations of histamine observed in all salted anchovies were below the thresholds set by current regulations (EC No. 1019/2013).

\subsection{Chemical analysis of salts}

\subsubsection{Chemical composition of salt samples}

The results of the chemical composition of salts are reported in Table 3. Within cation class, $\mathrm{Na}^{+}$was the most abundant component with a concentration between 332.85 and $374.00 \mathrm{~g} / \mathrm{Kg}$ among the samples. The differences among samples were not significant for this cation. The remaining cations were detected at very low concentrations in all samples, even though higher amounts of $\mathrm{K}^{+}$ and $\mathrm{Mg}^{2+}$ were found in samples FRA and MAR. These results are in line with what reported by Atkinson and Bingman (1997). With regards to anions, the most abundant chemical was $\mathrm{Cl}^{-}$and no significant difference was found among samples.

Among trace element, the highest concentrations were recorded for $\mathrm{Cr}$ in SAR (501.23 mg/Kg) and MIN (441.72 mg/Kg) samples, as well as Co in SAR salt $(116.32 \mathrm{mg} / \mathrm{Kg})$. Although very low concentration was found for these compounds, several significant differences were detected among sea salt samples. 

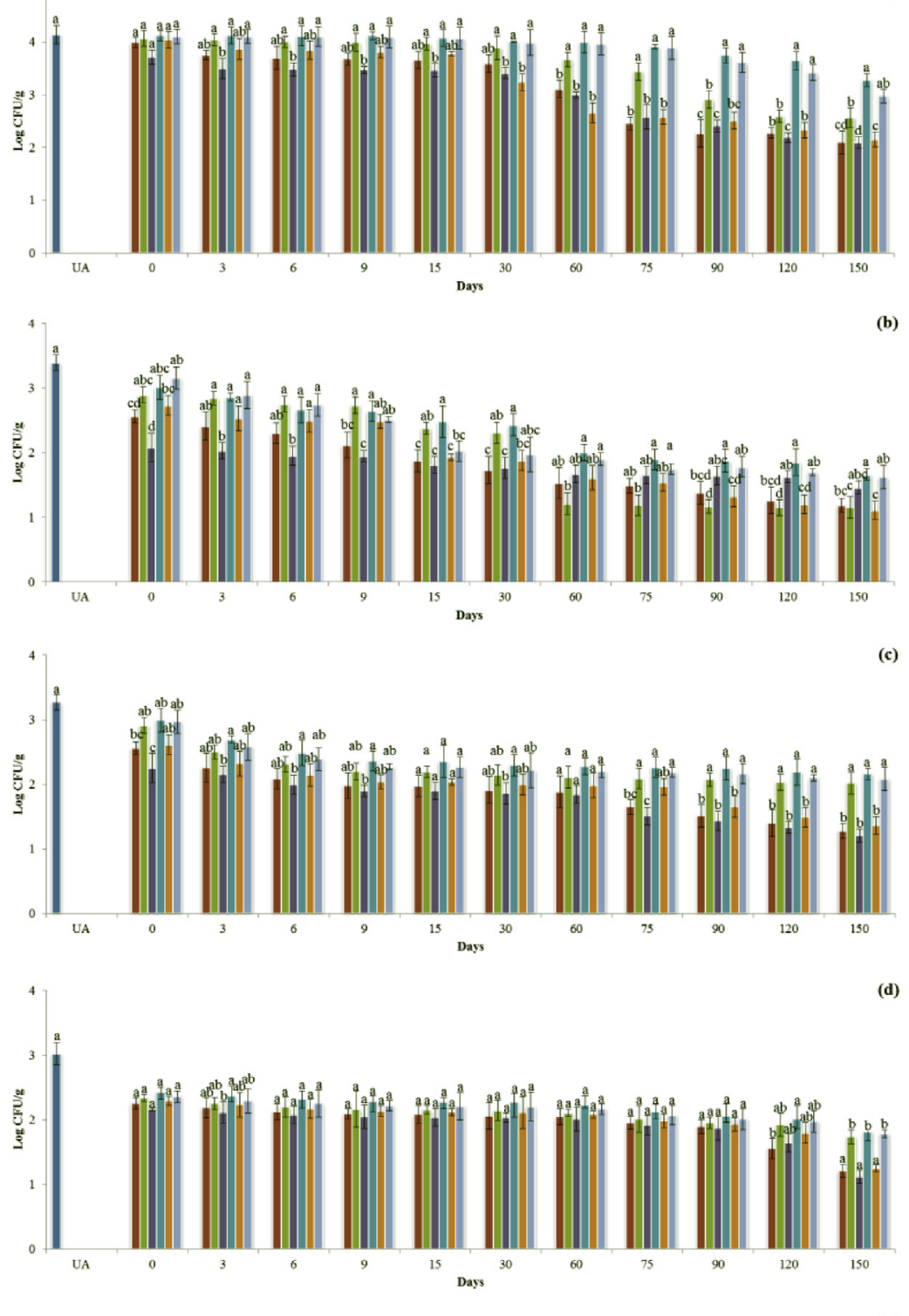

d)
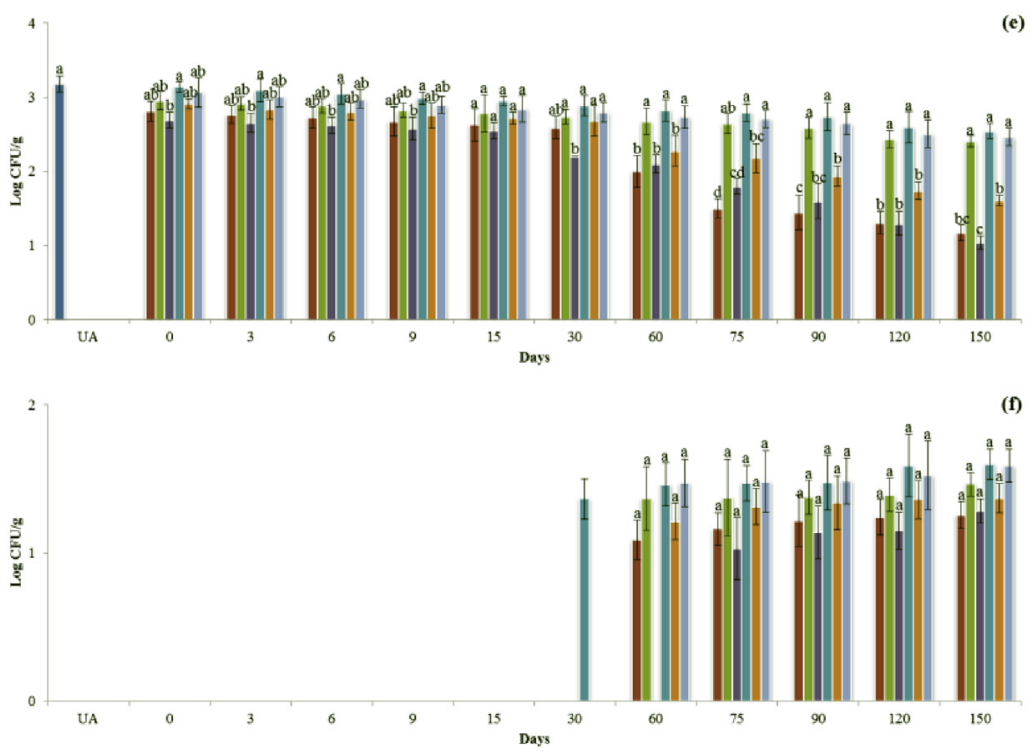

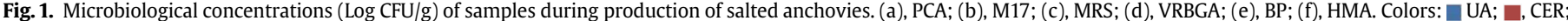
, FRA; —, MAR; , MIN; , SAR; _, SPA. Results indicate mean values of three experimental productions.

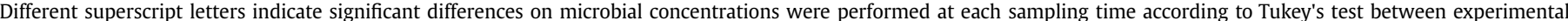
productions for $\mathrm{p} \leq \mathbf{0 . 0 5}$. (For interpretation of the references to color in this figure legend, the reader is referred to the Web version of this article.) 
Table 2

Values of histamine $(\mu \mathrm{g} / \mathrm{g})$ determined in the experimental salted anchovies during ripening period.

\begin{tabular}{|c|c|c|c|c|c|c|c|}
\hline \multirow[t]{2}{*}{ Days } & \multicolumn{6}{|c|}{ Level of histamine $(\mu \mathrm{g} / \mathrm{g})$} & \multirow[t]{2}{*}{ Statistical significance } \\
\hline & CER & FRA & MAR & MIN & SAR & SPA & \\
\hline 0 & $41.22 \pm 0.04^{\mathrm{a}}$ & $39.88 \pm 0.21^{\mathrm{c}}$ & $40.19 \pm 0.19^{b c}$ & $41.02 \pm 0.23^{\mathrm{a}}$ & $40.84 \pm 0.17^{\mathrm{a}}$ & $40.66 \pm 0.13^{\mathrm{ab}}$ & $*$ \\
\hline 75 & $32.41 \pm 0.26^{\mathrm{bc}}$ & $35.61 \pm 0.17^{\mathrm{ab}}$ & $32.17 \pm 0.13^{\mathrm{abc}}$ & $40.09 \pm 0.18^{a}$ & $30.13 \pm 0.17^{c}$ & $37.65 \pm 0.23^{\mathrm{ab}}$ & $* *$ \\
\hline 120 & $25.67 \pm 0.19^{\mathrm{e}}$ & $33.42 \pm 0.13^{c}$ & $21.10 \pm 0.16^{f}$ & $38.69 \pm 0.15^{a}$ & $26.83 \pm 0.27^{\mathrm{d}}$ & $34.44 \pm 0.18^{\mathrm{b}}$ & $* * *$ \\
\hline 150 & $22.38 \pm 0.10^{\mathrm{e}}$ & $30.13 \pm 0.20^{c}$ & $19.45 \pm 0.23^{f}$ & $34.24 \pm 0.23^{\mathrm{a}}$ & $23.45 \pm 0.24^{\mathrm{d}}$ & $32.11 \pm 0.23^{b}$ & $* * *$ \\
\hline
\end{tabular}

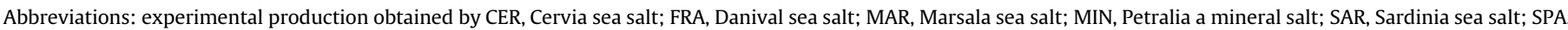
Santa Pola sea salt.

Results indicate mean values $\pm \mathrm{SD}$.

Data within a line followed by the same letter are not significantly different according to Tukey's test.

$p$ value: ${ }^{*}, p<0.05^{* *}, p<0.01 ;{ }^{* * *}, p<0.001$.

Table 3

Elemental composition of salts used for salting anchovies.

\begin{tabular}{|c|c|c|c|c|c|c|c|}
\hline & CER & FRA & MAR & MIN & SAR & SPA & Statistical significance \\
\hline \multicolumn{8}{|c|}{ Major Cations (g/Kg) } \\
\hline $\mathrm{Ca}^{+2}$ & $1.97 \pm 0.02^{\mathrm{c}}$ & $4.72 \pm 0.04^{\mathrm{a}}$ & $3.74 \pm 0.03^{b}$ & $0.52 \pm 0.02^{\mathrm{d}}$ & $1.02 \pm 0.01^{\mathrm{d}}$ & $1.93 \pm 0.02^{c}$ & $* *$ \\
\hline $\mathrm{K}^{+}$ & $0.97 \pm 0.05^{\mathrm{d}}$ & $6.42 \pm 0.08^{\mathrm{a}}$ & $4.22^{\mathrm{b}} \pm 0.09$ & $2.21^{\mathrm{cd}} \pm 0.04$ & $4.23^{\mathrm{bc}} \pm 0.05$ & $2.43^{\mathrm{bcd}} \pm 0.07$ & $* * *$ \\
\hline $\mathrm{Mg}^{+2}$ & $0.17^{c} \pm 0.01$ & $6.02^{\mathrm{a}} \pm 0.05$ & $3.06^{\mathrm{b}} \pm 0.03$ & $0.60^{c} \pm 0.01$ & $2.06^{c} \pm 0.02$ & $0.81^{\mathrm{c}} \pm 0.03$ & $* * *$ \\
\hline $\mathrm{Na}^{+}$ & $349.29 \pm 3.81^{\mathrm{a}}$ & $344.58 \pm 3.27^{a}$ & $374.00 \pm 3.65^{a}$ & $352.60 \pm 3.81^{a}$ & $332.85 \pm 3.24^{\mathrm{a}}$ & $357.88 \pm 3.57^{a}$ & N.S. \\
\hline \multicolumn{8}{|c|}{ Major Anions (g/Kg) } \\
\hline $\mathrm{Cl}^{-}$ & $538.52 \pm 6.17^{\mathrm{a}}$ & $531.25 \pm 5.88^{\mathrm{a}}$ & $576.62 \pm 6.02^{\mathrm{a}}$ & $543.60 \pm 5.90^{a}$ & $513.17 \pm 6.33^{a}$ & $551.77 \pm 6.21^{\mathrm{a}}$ & N.S. \\
\hline $\mathrm{SO}_{4}^{-2}$ & $24.21 \pm 0.34^{\mathrm{a}}$ & $28.51 \pm 0.98^{\mathrm{a}}$ & $26.78 \pm 0.47^{\mathrm{a}}$ & $24.59 \pm 0.81^{\mathrm{a}}$ & $25.45 \pm 0.99^{\mathrm{a}}$ & $25.69 \pm 0.15^{\mathrm{a}}$ & N.S. \\
\hline \multicolumn{8}{|c|}{ Trace elements (mg/Kg) } \\
\hline $\mathrm{Ba}$ & $0.93 \pm 0.08^{c}$ & $3.04 \pm 0.02^{a}$ & $1.69 \pm 0.01^{b}$ & $2.01 \pm 0.05^{b}$ & $1.91 \pm 0.004^{b}$ & $2.22 \pm 0.03^{b}$ & * \\
\hline $\mathrm{Be}$ & $<0.10^{\mathrm{a}}$ & $<0.10^{\mathrm{a}}$ & $<0.10^{\mathrm{a}}$ & $<0.10^{\mathrm{a}}$ & $<0.10^{\mathrm{a}}$ & $<0.10^{\mathrm{a}}$ & N.S. \\
\hline $\mathrm{Cd}$ & $1.52 \pm 0.05^{b}$ & $0.63 \pm 0.06^{c}$ & $1.53 \pm 0.02^{b}$ & $3.23 \pm 0.03^{a}$ & $3.21 \pm 0.05^{\mathrm{a}}$ & $1.23 \pm 0.03 b c$ & $*$ \\
\hline Co & $48.61 \pm 0.05^{b}$ & $38.23 \pm 0.08^{c}$ & $37.63 \pm 0.12^{b}$ & $47.33 \pm 0.21^{b}$ & $116.32 \pm 1.29^{a}$ & $37.12 \pm 0.28^{b}$ & $* * *$ \\
\hline $\mathrm{Cr}$ & $<0.10^{\mathrm{b}}$ & $<0.10^{\mathrm{b}}$ & $<0.10^{\mathrm{b}}$ & $441.72 \pm 3.66^{a}$ & $501.23 \pm 2.54^{a}$ & $<0.10^{\mathrm{b}}$ & $* * *$ \\
\hline $\mathrm{Cu}$ & $22.10 \pm 0.02^{\mathrm{ab}}$ & $25.42 \pm 0.87^{\mathrm{a}}$ & $21.53 \pm 0.66^{a b c}$ & $17.23 \pm 0.39^{b c}$ & $14.62 \pm 0.14^{c}$ & $24.62 \pm 0.21^{\mathrm{a}}$ & $* *$ \\
\hline $\mathrm{Mn}$ & $33.12 \pm 0.11^{\mathrm{cd}}$ & $97.23 \pm 1.01^{\mathrm{a}}$ & $23.32 \pm 0.37$ de & $60.21 \pm 0.41^{b}$ & $45.92 \pm 0.09^{b}$ & $15.53 \pm 0.10^{\mathrm{e}}$ & $* * *$ \\
\hline $\mathrm{Ni}$ & $<0.10^{c}$ & $<0.10^{c}$ & $<0.10^{\mathrm{c}}$ & $23.21 \pm 0.02^{b}$ & $56.52 \pm 0.06^{a}$ & $<0.10^{\mathrm{c}}$ & $* * *$ \\
\hline $\mathrm{Pb}$ & $11.63 \pm 0.07^{\mathrm{ab}}$ & $6.10 \pm 0.11^{c}$ & $1.88 \pm 0.03^{\mathrm{d}}$ & $2.91 \pm 0.04^{\mathrm{d}}$ & $9.92 \pm 0.06^{b}$ & $13.21 \pm 0.01^{\mathrm{a}}$ & $* * *$ \\
\hline $\mathrm{Zn}$ & $8.53 \pm 0.07^{\mathrm{a}}$ & $0.31 \pm 0.02^{\mathrm{e}}$ & $2.64 \pm 0.02^{\mathrm{cd}}$ & $5.55 \pm 0.01^{b}$ & $3.96 \pm 0.03^{c}$ & $1.61 \pm 0.02$ de & $* * *$ \\
\hline
\end{tabular}

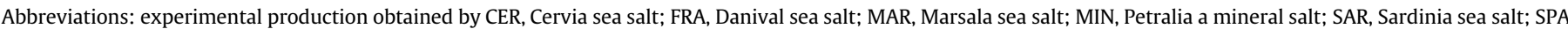
Santa Pola sea salt.

Results indicate mean values \pm SD.

Data within a line followed by the same letter are not significantly different according to Tukey's test.

$p$ value: ${ }^{*}, p<0.05^{* *}, p<0.01{ }^{* * *}, p<0.001$, N.S., not significant.

\section{Biplot (axes F1 and F2: $90.59 \%$ )}

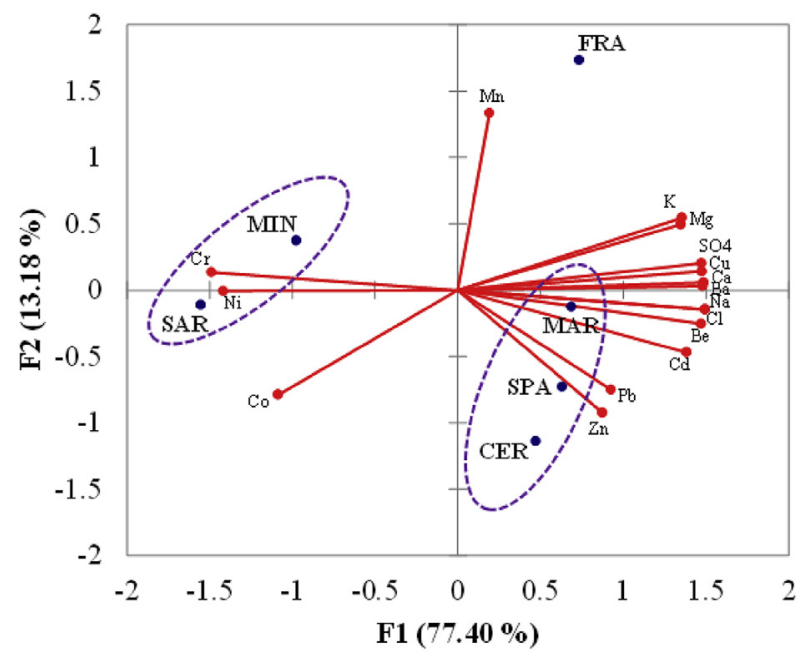

Fig. 2. Biplot graph showing the distribution of different salts in relation to the content of major cations, major anions and trace elements.
In order to better evaluate the differences among salt samples, the data set based on chemical composition was subjected to PCA. The biplot illustrated in Fig. 2 highlights the distribution of the different salts in relation to their chemical composition. CER, MAR and SPA salts clustered into one main group that was statistically correlated with $\mathrm{Zn}$ and $\mathrm{Pb}$ concentrations. On the other quadrant of biplot, SAR and MIN salts were associated to $\mathrm{Cr}$ and Ni elements. Sample FRA resulted mainly related to $\mathrm{Mn}$ (Table 3 ).

Trace elements presented in small amounts play an important role in enzymatic reactions which characterize the process of maturation of salted anchovies (Ghaly, Dave, Budge, \& Brooks, 2010; Hultin, 1994). In some cases, they act as co-factors of enzymatic reactions of lipid oxidation and, indirectly, determine the appearance of off-flavor and rancidity in the final products (in't Veld, 1996). In addition, these trace elements might interfere with the activity of exchange between cell membranes of the eukaryotes (anchovies) and prokaryotes (microorganisms) by inhibiting or promoting different metabolic activities (Ghaly et al., 2010). Consequently, the chemical composition of the salts might affect the organoleptic and sensory characteristics of the final product.

\subsubsection{VOCs in salt samples}

Volatile organic components might affect significantly the 
sensory characteristics of salted anchovies (Triqui \& Reineccius, 1995a, 1995b). In this investigation, VOC profiles were determined for the salts and for the salted anchovies.

The salts were characterized by 27 VOCs belonging to 4 chemical classes (Table 4). The explorative multivariate analysis based on HCMA was carried out to highlight the distribution of the different salts in relation to the different VOCs profiles generated (Fig. 3a). The dendrogram of heat map plot showed the differences of each salt. Alkanes (38.74-85.74\%), alcohols (14.26-43.69\%), alkenes (2.58-38.71\%) and aldehydes (0.32-4.53\%) constituted the major VOC classes for all salts. Alkanes were represented by 13 compounds, among which octadecane (7.07-48.39\%) was detected at the highest concentrations in all salts except SPA. Octadecane is responsible for the emission of fuel-like odors (Chung, Eiserich, \& Shibamoto, 1993). The presence of this hydrocarbon in sea salts from the western coast of France and the Sal Island of the Cape Verde archipelago was already reported by Silva et al. (2015). The presence of this compound in salt is mainly due to the marine environment that contributes to the enrichment of the raw salts in various volatile compounds (Silva et al., 2015).

Within the class of alcohol, eight different compounds were detected and the dodecanol was found at highest level

Table 4

Concentration of VOCs derived from crude salts.

\begin{tabular}{|c|c|c|c|c|c|c|}
\hline \multirow[t]{2}{*}{ Chemical compounds $^{\mathrm{a}}$} & \multicolumn{6}{|l|}{ Raw salts ${ }^{\mathrm{b}}$} \\
\hline & CER & FRA & MAR & MIN & SAR & SPA \\
\hline heptane, $2,2,4,6,6$,-pentamethyl & n.d. & n.d. & n.d. & $20.13 \pm 0.44$ & n.d. & n.d. \\
\hline n-pentanal & n.d. & n.d. & $2.64 \pm 0.15$ & n.d. & n.d. & n.d. \\
\hline n-decane & n.d. & n.d. & n.d. & $9.16 \pm 0.11$ & n.d. & n.d. \\
\hline undecane, 4,6 dimethyl & n.d. & n.d. & n.d. & $2.37 \pm 0.09$ & n.d. & n.d. \\
\hline tridecene & n.d. & n.d. & n.d. & $3.48 \pm 0.06$ & n.d. & n.d. \\
\hline 1-octanol,3,7,dimethyl & n.d. & n.d. & n.d. & $3.21 \pm 0.05$ & n.d. & n.d. \\
\hline heptan, 2,2,4-trimethil & $29.85 \pm 0.42$ & n.d. . & $23.24 \pm 0.61$ & n.d. & $35.49 \pm 1.01$ & n.d. \\
\hline pinene alfa & n.d. & n.d. & $2.59 \pm 0.02$ & n.d. & n.d. & n.d. \\
\hline hexane,2,2,5-trimethil & $15.42 \pm 1.12$ & $11.94 \pm 1.04$ & $14.15 \pm 1.87$ & $16.11 \pm 1.92$ & $14.09 \pm 1.41$ & $15.55 \pm 0.99$ \\
\hline n-eicosane & n.d. & n.d. & n.d. & n.d. & n.d. & $22.84 \pm 0.87$ \\
\hline hexadecene & n.d. & n.d. & n.d. & $1.14 \pm 0.03$ & n.d. & n.d. \\
\hline decanol & $8.39 \pm 0.04$ & n.d. & n.d. & n.d. & $11.86 \pm 0.02$ & n.d. \\
\hline heptane,2,5-dimethyl & n.d. & n.d. & n.d. & n.d. & n.d. & $2.81 \pm 0.08$ \\
\hline dihydrocitronello/nonanol & n.d. & n.d. & n.d. & n.d. & n.d. & $12.20 \pm 0.31$ \\
\hline lavandulol & $0.35 \pm 0.04$ & $0.96 \pm 0.08$ & n.d. & n.d. & n.d. & n.d. \\
\hline 5-hexen-3-ol & $1.60 \pm 0.18$ & n.d. & n.d. & n.d. & $2.22 \pm 0.05$ & n.d. \\
\hline tetradecene & n.d. & n.d. & n.d. & $34.10 \pm 2.11$ & n.d. & n.d. \\
\hline octadecane & $36.19 \pm 0.63$ & $39.21 \pm 0.56$ & $34.16 \pm 0.85$ & $7.07 \pm 0.04$ & $48.39 \pm 0.43$ & n.d. \\
\hline docosane & $1.41 \pm 0.01$ & $1.71 \pm 0.02$ & $6.29 \pm 0.41$ & n.d. & $1.87 \pm 0.14$ & n.d. \\
\hline dodecanol & $9.12 \pm 0.14$ & $30.47 \pm 0.31$ & $21.70 \pm 0.87$ & $19.34 \pm 0.08$ & $0.18 \pm 0.04$ & $31.49 \pm 0.36$ \\
\hline heneicosane & n.d. & n.d. & n.d. & n.d. & n.d. & $1.97 \pm 0.08$ \\
\hline tricosane & n.d. & $9.05 \pm 0.74$ & n.d. & n.d. & n.d. & $9.08 \pm 0.06$ \\
\hline nonanal & $0.32 \pm 0.01$ & $3.17 \pm 0.23$ & $1.90 \pm 0.05$ & n.d. & n.d. & $2.95 \pm 0.04$ \\
\hline 1-pentadecanol & $0.47 \pm 0.01$ & $1.06 \pm 0.03$ & n.d. & n.d. & n.d. & n.d. \\
\hline octadecanol & $0.65 \pm 0.00$ & $1.93 \pm 0.10$ & n.d. & n.d. & n.d. & n.d. \\
\hline 1-methil-trans-2-2ethylcycloexane & n.d. & n.d. & n.d. & n.d. & n.d. & $2.50 \pm 0.21$ \\
\hline cyclopentadecane & n.d. & n.d. & n.d. & n.d. & n.d. & $2.61 \pm 0.07$ \\
\hline
\end{tabular}

${ }^{a}$ Results indicate mean percentage values of three measurements and are expressed as relative peak areas (peak area of each compound/total area of the significant and common peaks to all samples) $\times 100$.

b Different salts used for salting process: CER (Cervia sea salt), FRA (Danival sea salt), MAR (Marsala sea salt), MIN (Petralia a mineral salt), SAR (Pula sea salt), SPA (Santa Pola sea salt).

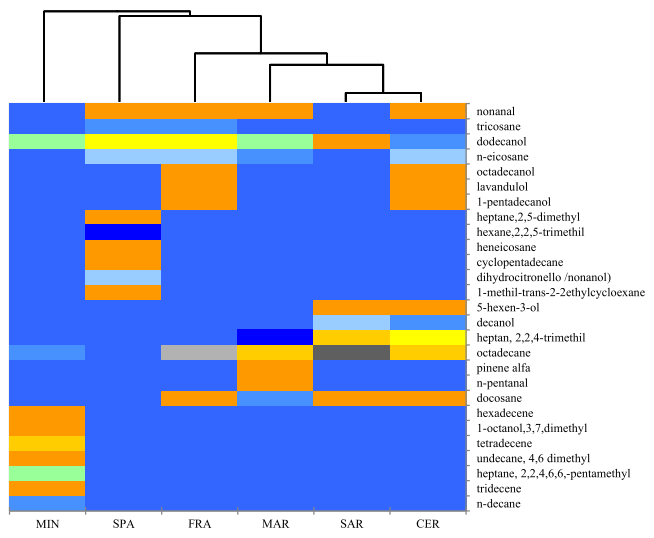

(a)

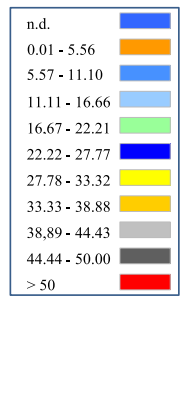

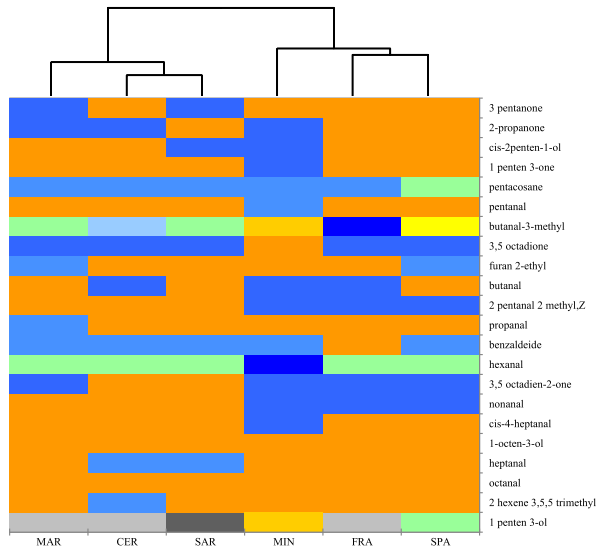

(b)

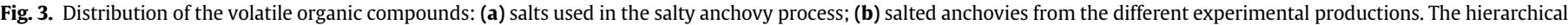

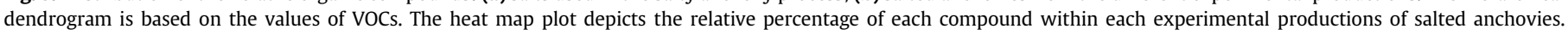
Abbreviations: CER, Cervia sea salt; FRA, Danival sea salt; MAR, Marsala sea salt; MIN, Petralia a mineral salt; SAR, Sardinia sea salt; SPA, Santa Pola sea salt. 
(7.07-48.39\%) in all samples. Dodecanol generates floral odors (Silva et al., 2015). Alkenes and aldehydes were present at low concentrations.

Fig. 3a reports the statistical multivariate analysis of VOCs emitted by the salts. The six salts were clearly separated in clusters with different levels of dissimilarity. The samples MIN and SPA showed the highest level of dissimilarity. On the other hand, the lowest level of dissimilarity was found between the samples SAR and CER.

\subsubsection{VOCs in salted anchovies}

Twenty-two VOCs belonging to 5 classes, including aldehydes, ketones, alcohols, alkanes and furans (Table 5) were identified in ripened salted anchovies. The aldehydes constituted the major classes of VOCs for all salted anchovies (41.69-51.37\%). 3-methylbutanal was found at the highest concentration in MIN (24.32\%) and SPA (20.73\%) and produces apple-like odor (Lewis, 2007, p. 719). The alcohols (16.68-33.80\%) represented the second class in terms of percentage and the most abundant compound was 1penten-3-ol found in SAR (31.23\%) and FRA (28.83\%) samples. This alchenol is known for the production of butter and grass odors (Josephson, 1991; Macleod \& Ames, 1986).

The classes of alkanes (10.28-17.17\%), ketones (0.95-8.66\%) and furans $(2.37-4.30 \%)$ were represented by two, five and one compounds, respectively. Except for MIN trial, cis-4-heptanal and 1penten-3-one were found in all experimental productions. cis-4heptanal and 1-penten-3-one might contribute to potato-like and tomato-like odors, respectively (Deibler \& Delwiche, 2003; Hui, 2007). cis-2-penten-1-ol, responsible for fruity odor (Ash \& Ash, 2006) was present in all experimental productions, except MIN and SAR.

Fig. 3b shows the dendrogram resulting from cluster analysis and the heat map based on concentration and distribution of VOCs among the experimental samples. The relationships among the salted anchovies depends on the concentrations of VOCs. Cluster analysis determined the formation of two main clusters (Fig. 3b).
Among the trials MAR, CER and SAR a very low level of dissimilarity was found, since they clustered together into one main group. Another main group was found for the remaining trials FRA, SPA and MIN.

Among the 27 compounds present in the different salts used for the salting anchovies, only nonanal and pentanal were found in the final product. In particular, nonanal was found in the salt samples SPA, FRA, MAR and CER and in the salted anchovies of the trials CER, MAR and SAR. Pentanal was only detected in one salt sample (MAR) but was identified in all samples of salted anchovies. Nonanal and pentanal are responsible for fatty odor (Triqui \& Reineccius, 1995a). The disappearance of most VOCs of salts might be due to the enzymatic activities and the oxidation processes that occur during the maturation process of salted anchovies (Triqui \& Reineccius, 1995a, 1995b; Triqui \& Zouine, 1999).

\subsection{Sensory attributes of salted anchovies}

The evaluation of the salted anchovies from the six experimental productions is reported in Table 6.

Statistically significant differences $(p<0.05)$ were found among trials. The anchovies of trials CER, MAR and SAR showed the highest scores for color homogeneity and pink descriptors. The same trend was recorded for the descriptors associated with salted anchovies and fresh fish odors. With regards to off-odors, the highest values of putrid (3.03) and rancid (3.67) odour were found for the trials MIN and SPA that also shared the highest scores for compactness (6.23) and dryness (3.00). MAR, CER and SAR trails were characterized by the highest values of salted anchovies taste. MIN production was characterized by the highest values of off-flavors such as bitter (3.04), salt (5.14), raw blood (3.11), putrid (4.31) and rancid (3.70). The type of salt did not influence gummy attribute. The highest values of overall enjoyment were registered for MAR salted anchovies.

The results of the sensory evaluation were subjected to a statistical multivariate analysis (Fig. 4). A symmetric plot of the

Table 5

Concentration of VOCs at the end of the ripening process of salted anchovies.

\begin{tabular}{|c|c|c|c|c|c|c|}
\hline \multirow[t]{2}{*}{ Chemical compounds ${ }^{\mathrm{a}}$} & \multicolumn{6}{|c|}{ Salted anchovy } \\
\hline & CER & FRA & MAR & MIN & SAR & SPA \\
\hline 510 propanal & $3.21 \pm 0.24$ & $2.87 \pm 0.43$ & $3.95 \pm 0.45$ & $1.97 \pm 0.17$ & $3.31 \pm 0.30$ & $2.90 \pm 0.14$ \\
\hline 605 butanal & n.d. & n.d. & $1.99 \pm 0.04$ & n.d. & $1.10 \pm 0.08$ & $1.34 \pm 0.09$ \\
\hline 500 2-propanone & n.d. & $3.83 \pm 0.32$ & n.d. & n.d. & $1.74 \pm 0.10$ & $2.52 \pm 0.14$ \\
\hline 710 furan-2-ethyl & $3.41 \pm 0.10$ & $2.37 \pm 0.11$ & $4.02 \pm 0.04$ & $3.09 \pm 0.14$ & $2.95 \pm 0.17$ & $4.30 \pm 0.29$ \\
\hline 650 butanal-3-methyl & $9.77 \pm 0.14$ & $18.19 \pm 0.12$ & $14.10 \pm 0.10$ & $24.32 \pm 0.36$ & $13.15 \pm 0.22$ & $20.73 \pm 0.24$ \\
\hline 695 pentanal & $2.17 \pm 0.02$ & $3.35 \pm 0.05$ & $1.62 \pm 0.06$ & $3.96 \pm 0.11$ & $2.79 \pm 0.24$ & $3.77 \pm 0.17$ \\
\hline 710 3-pentanone & $2.59 \pm 0.09$ & $3.59 \pm 0.08$ & n.d. & $2.33 \pm 0.21$ & n.d. & $2.25 \pm 0.02$ \\
\hline 680 1-penten-3-one & $1.23 \pm 0.04$ & $1.24 \pm 0.01$ & $0.95 \pm 0.05$ & n.d. & $0.86 \pm 0.05$ & $1.47 \pm 0.02$ \\
\hline 805 hexanal & $15.42 \pm 1.12$ & $11.94 \pm 1.04$ & $14.15 \pm 1.87$ & $16.11 \pm 1.92$ & $14.09 \pm 1.41$ & $15.55 \pm 0.99$ \\
\hline 690 1-penten-3-ol & $27.23 \pm 2.17$ & $28.83 \pm 3.01$ & $27.68 \pm 1.85$ & $24.99 \pm 1.97$ & $31.23 \pm 2.96$ & $12.57 \pm 1.74$ \\
\hline 755 2-pentanal-2-methyl & $1.36 \pm 0.04$ & n.d. & $2.44 \pm 0.02$ & n.d. & $1.12 \pm 0.11$ & n.d. \\
\hline 916 heptanal & $4.71 \pm 0.04$ & $3.04 \pm 0.03$ & $3.55 \pm 0.08$ & $3.37 \pm 0.04$ & $4.01 \pm 0.02$ & $3.87 \pm 0.09$ \\
\hline 902 cis-4-heptanal & $2.12 \pm 0.23$ & $1.06 \pm 0.07$ & $1.11 \pm 0.06$ & n.d. & $1.63 \pm 0.04$ & $1.13 \pm 0.05$ \\
\hline 755 cis-2-penten-1-ol & $1.30 \pm 0.04$ & $1.62 \pm 0.03$ & $2.18 \pm 0.11$ & n.d. & n.d. & $1.90 \pm 0.21$ \\
\hline 1012 octanal & $2.84 \pm 0.21$ & $1.24 \pm 0.02$ & $1.91 \pm 0.02$ & $1.63 \pm 0.11$ & $2.14 \pm 0.04$ & $1.54 \pm 0.05$ \\
\hline 3,5-octadione & n.d. & n.d. & n.d. & $1.26 \pm 0.09$ & n.d. & n.d. \\
\hline 978 1-octen-3-ol & $3.37 \pm 0.14$ & $1.35 \pm 0.06$ & $2.22 \pm 0.04$ & $2.09 \pm 0.08$ & $2.57 \pm 0.20$ & $2.20 \pm 0.10$ \\
\hline 1127 nonanal & $1.52 \pm 0.11$ & n.d. & $0.98 \pm 0.05$ & n.d. & $1.35 \pm 0.21$ & n.d. \\
\hline 2500 pentacosane & $7.02 \pm 0.21$ & $10.23 \pm 1.02$ & $9.39 \pm 1.17$ & $7.20 \pm 0.78$ & $7.29 \pm 0.74$ & $13.67 \pm 1.21$ \\
\hline 985 3,5,5-trimethyl-2-hexene & $4.04 \pm 0.44$ & $2.11 \pm 0.01$ & $2.85 \pm 0.21$ & $3.08 \pm 0.21$ & $3.29 \pm 0.24$ & $3.50 \pm 0.17$ \\
\hline 986 benzaldeide & $5.07 \pm 0.41$ & $3.16 \pm 0.16$ & $4.92 \pm 0.02$ & $4.58 \pm 0.19$ & $3.93 \pm 0.11$ & $4.79 \pm 0.21$ \\
\hline 1089 3,5-octadien-2-one & $1.63 \pm 0.08$ & n.d. & n.d. & n.d. & $1.44 \pm 0.02$ & n.d. \\
\hline
\end{tabular}

${ }^{a}$ Results indicate mean percentage values of three measurements and are expressed as relative peak areas (peak area of each compound/total area of the significant and common peaks to all samples) $\times 100$.

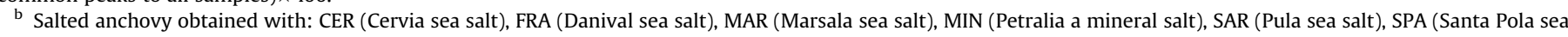
salt). 
Table 6

Sensory characteristics of experimental productions of salted anchovies at the end of the ripening process.

\begin{tabular}{|c|c|c|c|c|c|c|c|c|}
\hline \multirow[t]{2}{*}{ Descriptors } & \multicolumn{6}{|c|}{ Day 150} & \multirow[t]{2}{*}{ SEM } & \multirow[t]{2}{*}{ Statistical significance } \\
\hline & CER & FRA & MAR & MIN & SAR & SPA & & \\
\hline \multicolumn{9}{|l|}{ Aspect } \\
\hline color homogeneity & $8.21^{\mathrm{a}}$ & $7.61^{\mathrm{b}}$ & $8.33^{\mathrm{a}}$ & $4.81^{\mathrm{d}}$ & $8.21^{\mathrm{a}}$ & $6.21^{c}$ & 0.32 & $* * *$ \\
\hline pink & $6.11^{\mathrm{a}}$ & $3.51^{\mathrm{b}}$ & $6.22^{\mathrm{a}}$ & $3.37^{\mathrm{b}}$ & $6.16^{\mathrm{a}}$ & $3.47^{\mathrm{b}}$ & 0.33 & $* * *$ \\
\hline brown & $3.78^{c}$ & $5.11^{\mathrm{ab}}$ & $3.66^{c}$ & $5.27^{\mathrm{a}}$ & $4.03^{c}$ & $4.88^{\mathrm{b}}$ & 0.16 & $* *$ \\
\hline \multicolumn{9}{|l|}{ Odour } \\
\hline salted anchovies & $6.11^{\mathrm{a}}$ & $2.64^{c}$ & $6.38^{\mathrm{a}}$ & $3.34^{\mathrm{b}}$ & $6.18^{\mathrm{a}}$ & $3.26^{\mathrm{b}}$ & 0.39 & $* * *$ \\
\hline fresh fish & $6.81^{\mathrm{a}}$ & $4.31^{\mathrm{c}}$ & $6.26^{\mathrm{b}}$ & $4.10^{c}$ & $6.15^{\mathrm{b}}$ & $4.02^{c}$ & 0.28 & $* *$ \\
\hline putrid & $1.21^{\mathrm{c}}$ & $2.57^{\mathrm{b}}$ & $1.10^{c}$ & $3.03^{\mathrm{a}}$ & $1.11^{\mathrm{c}}$ & $3.11^{\mathrm{a}}$ & 0.22 & $* *$ \\
\hline rancid & $1.03^{c}$ & $2.11^{\mathrm{b}}$ & $1.02^{\mathrm{c}}$ & $3.67^{\mathrm{a}}$ & $1.05^{\mathrm{c}}$ & $2.48^{\mathrm{b}}$ & 0.24 & $* *$ \\
\hline \multicolumn{9}{|l|}{ Texture } \\
\hline compactness & $4.60^{\mathrm{cd}}$ & $5.11^{\mathrm{b}}$ & $4.58^{\mathrm{cd}}$ & $6.23^{\mathrm{a}}$ & $4.44^{\mathrm{d}}$ & $4.94^{\mathrm{bc}}$ & 0.15 & $*$ \\
\hline gummy & $4.37^{\mathrm{a}}$ & $4.22^{\mathrm{a}}$ & $4.21^{\mathrm{a}}$ & $4.14^{\mathrm{a}}$ & $4.24^{\mathrm{a}}$ & $4.26^{\mathrm{a}}$ & 0.03 & N.S. \\
\hline dryness & $1.92^{\mathrm{bc}}$ & $2.24^{\mathrm{b}}$ & $1.65^{c}$ & $2.23^{\mathrm{b}}$ & $1.68^{c}$ & $3.00^{\mathrm{a}}$ & 0.12 & $*$ \\
\hline \multicolumn{9}{|l|}{ Taste } \\
\hline salted anchovies & $6.18^{\mathrm{a}}$ & $5.68^{\mathrm{b}}$ & $6.27^{\mathrm{a}}$ & $5.30^{c}$ & $6.11^{\mathrm{a}}$ & $5.52^{\mathrm{bc}}$ & 0.09 & $*$ \\
\hline bitter & $1.50^{c}$ & $1.93^{\mathrm{b}}$ & $1.63^{c}$ & $3.04^{\mathrm{a}}$ & $1.90^{\mathrm{b}}$ & $1.97^{\mathrm{b}}$ & 0.12 & $*$ \\
\hline salt & $3.72^{\mathrm{b}}$ & $3.72^{\mathrm{b}}$ & $3.36^{c}$ & $5.14^{\mathrm{a}}$ & $2.99^{\mathrm{d}}$ & $3.93^{\mathrm{b}}$ & 0.16 & $* *$ \\
\hline ham & $2.70^{\mathrm{ab}}$ & $1.56^{\mathrm{C}}$ & $3.00^{\mathrm{a}}$ & $1.14^{\mathrm{d}}$ & $2.30^{\mathrm{b}}$ & $1.00^{\mathrm{d}}$ & 0.19 & $* *$ \\
\hline raw blood & $1.21^{\mathrm{b}}$ & $2.77^{\mathrm{a}}$ & $1.11^{\mathrm{b}}$ & $3.11^{\mathrm{a}}$ & $1.38^{\mathrm{b}}$ & $3.08^{\mathrm{a}}$ & 0.22 & $* *$ \\
\hline putrid & $1.05^{\mathrm{d}}$ & $1.52^{\mathrm{bc}}$ & $1.39^{c}$ & $4.31^{\mathrm{a}}$ & $1.43^{c}$ & $1.75^{\mathrm{b}}$ & 0.27 & $* * *$ \\
\hline rancid & $1.75^{\mathrm{cd}}$ & $3.15^{\mathrm{b}}$ & $1.40^{\mathrm{d}}$ & $3.70^{\mathrm{a}}$ & $2.00^{c}$ & $3.80^{\mathrm{a}}$ & 0.23 & $* *$ \\
\hline Overall enjoyment & $6.28^{\mathrm{b}}$ & $5.10^{c}$ & $7.21^{\mathrm{a}}$ & $3.11^{\mathrm{e}}$ & $6.08^{b}$ & $4.02^{\mathrm{d}}$ & 0.34 & $* * *$ \\
\hline
\end{tabular}


Santa Pola sea salt.

Result indicate mean value.

Data within a line followed by the same letter are not significantly different according to Tukey's test.

$p$ value: ${ }^{*}, p<0.05^{* *}, p<0.01 ;{ }^{* * *}, p<0.001$; N.S., not significant.

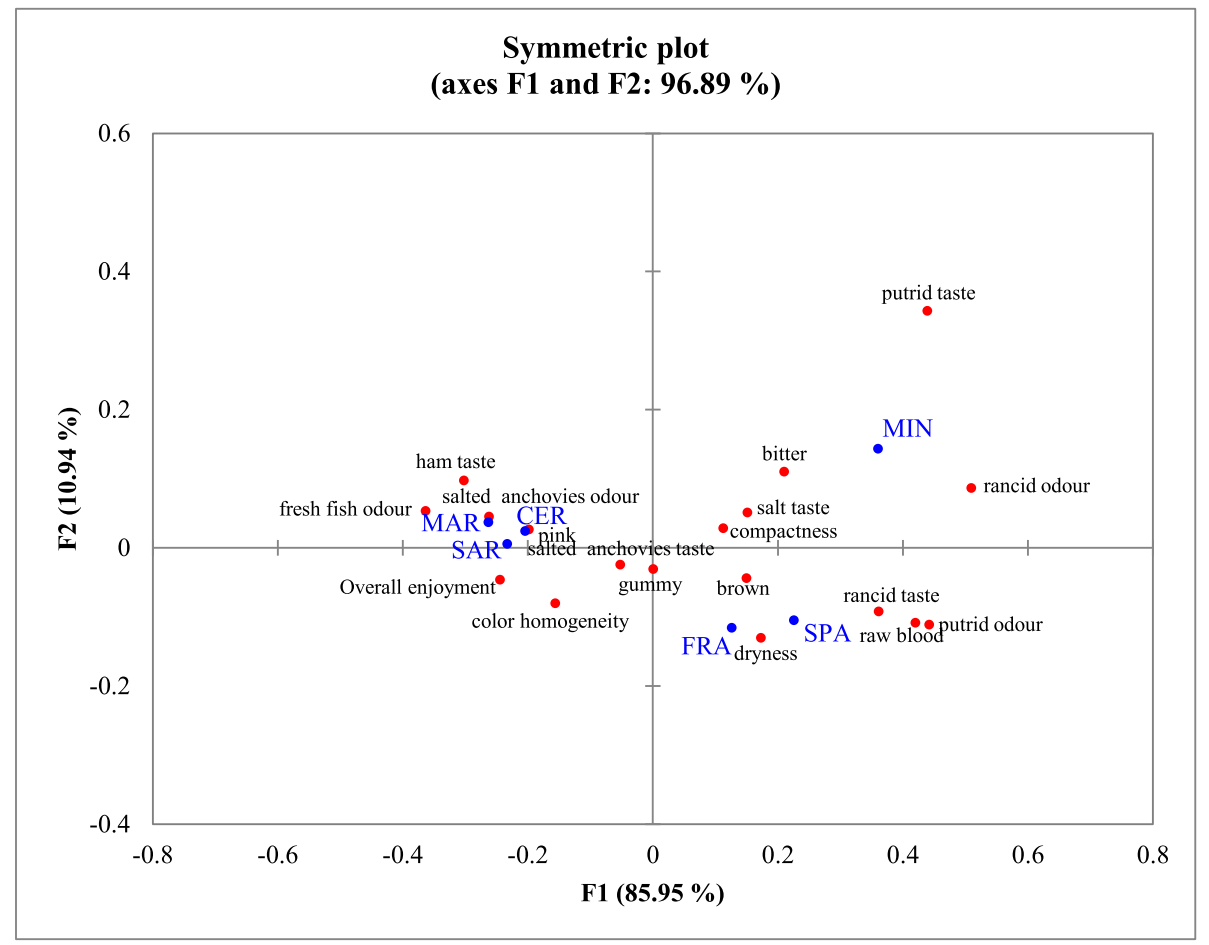

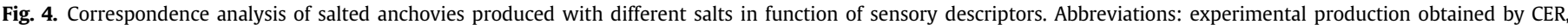
Cervia sea salt; FRA, Danival sea salt; MAR, Marsala sea salt; MIN, Petralia a mineral salt; SAR, Sardinia sea salt; SPA, Santa Pola sea salt.

correspondence analysis (CA) explained $96.89 \%$ of inertia. All experimental trials were mainly separated along factor F1 that explained more than $85 \%$ of total variability. Trials MAR, CER and SAR were grouped for desirable taste and odour descriptors. The 
experimental production performed with SPA and FRA salts differed from the other trials and were mainly correlated to dryness, brown colour, putrid odour, rancid and raw blood taste. The highest diversity along both F1 and F2 axes was found for the trial MIN correlated to bitter and putrid taste, rancid odour and compactness.

The results of this study indicated that salts with different chemical composition determine differences in sensory profiles of salted anchovies.

\section{Conclusions}

The aim of this study was to evaluate the effect of salt of different geographical origins on the microbiological, chemical and sensory characteristics of salted anchovies. The salts showed significant differences in terms of composition (chemical/VOC's), and significant differences were found for concentrations of all microbial group monitored (total aerobic mesophilic microorganisms, LAB, Staphylococcaceae and Enterobacteriaceae), except EHA, among salted anchovies produced with different raw salt. Those differences were confirmed by the analysis of the VOC's profiles generated by salted anchovies at the end of the ripening period. The heterogeneity in terms of chemical composition and VOC profiles, determines differences in the final product also confirmed by different sensory scores.

\section{Acknowledgements}

This work was financially supported by the project PON02_00451_3362121 PESCATEC "Development of a sustainable and competitive Sicilian fishery through technological innovation" of the Italian Ministry of Education, University and Research. The authors are grateful to Professor Luca Settanni for her significant support in analysis of data.

\section{Appendix A. Supplementary data}

Supplementary data related to this article can be found at https://doi.org/10.1016/j.foodcont.2018.05.003.

\section{References}

Akolkar, A. V., Durai, D., \& Desai, A. J. (2010). Halobacterium sp. SP1(1) as a starter culture for accelerating fish sauce fermentation. Journal of Applied Microbiology, 109(1), 44-53.

Alfonzo, A., Martorana, A., Guarrasi, V., Barbera, M., Gaglio, R., Santulli, A., et al. (2017b). Effect of the lemon essential oils on the safety and sensory quality of salted sardines (Sardina pilchardus Walbaum 1792). Food Control, 73, 1265-1274.

Alfonzo, A., Randazzo, W., Barbera, M., Sannino, C., Corona, O., Settanni, L., et al. (2017a). Effect of salt concentration and extremely halophilic archaea on the safety and quality characteristics of traditional salted anchovies. Journal of Aquatic Food Product Technology, 26(5), 620-637.

Alves, S. P., Alfaia, C. M., Škrbić, B. D., Živančev, J. R., Fernandes, M. J., Bessa, R. J., et al, (2017). Screening chemical hazards of dry fermented sausages from distinct origins: Biogenic amines, polycyclic aromatic hydrocarbons and heavy elements. Journal of Food Composition and Analysis, 59, 124-131.

Antón, J., Oren, A., Benlloch, S., Rodríguez-Valera, F., Amann, R., \& Rosselló-Mora, R. (2002). Salinibacter ruber gen. nov., sp. nov., a novel, extremely halophilic member of the Bacteria from saltern crystallizer ponds. International Journal of Systematic and Evolutionary Microbiology, 52(2), 485-491.

APHA. (2015). Compendium of methods for the microbiological examination of foods (5th ed.). New York: APHA Press.

Aponte, M., Blaiotta, G., Francesca, N., \& Moschetti, G. (2010). Could halophilic archaea improve the traditional salted anchovies (Engraulis encrasicholus L.) safety and quality? Letters in Applied Microbiology, 51(6), 697-703.

Ash, M., \& Ash, I. (2006). Handbook of flavors and fragrances. New York: Synapse Information Resources.

Atkinson, M. J., \& Bingman, C. (1997). Elemental composition of commercial sea salts. Journal of Aquariculture and Aquatic Sciences, 8(2), 39-43.

Campello, F. (1985). Approche microbiologique de l'anchoítage. Revue des travaux de l'Institut des pêches maritimes, 47, 217-226.
Chung, T. Y., Eiserich, J. P., \& Shibamoto, T. (1993). Volatile compounds isolated from edible Korean chamchwi (Aster scaber Thunb). Journal of Agricultural and Food Chemistry, 41(10), 1693-1697.

Coppes, Z., Pavlisko, A., \& Vecchi, S. D. (2002). Texture measurements in fish and fish products. Journal of Aquatic Food Product Technology, 11(1), 89-105.

Czerner, M., Tomás, M. C., \& Yeannes, M. I. (2011). Ripening of salted anchovy (Engraulis anchoita): Development of lipid oxidation, colour and other sensorial characteristics. Journal of the Science of Food and Agriculture, 91(4), 609-615.

Czerner, M., \& Yeannes, M. I. (2014). Bacterial contribution to salted anchovy (Engraulis anchoita Hubbs \& Marinni, 1935) ripening process. Journal of Aquatic Food Product Technology, 23(2), 102-114.

Dapkevicius, M. L. E., Nout, M. R., Rombouts, F. M., Houben, J. H., \& Wymenga, W. (2000). Biogenic amine formation and degradation by potential fish silage starter microorganisms. International Journal of Food Microbiology, 57(1-2), 107-114.

Deibler, K. D., \& Delwiche, J. (2003). Handbook of flavor characterization: Sensory analysis, chemistry, and physiology. New York: CRC Press.

Eerola, S., Hinkkanen, R., Lindfors, E., \& Hirvi, T. (1992). Liquid chromatographic determination of biogenic amines in gradry sausages. Journal of AOAC International, 76(3), 575-577.

Gaglio, R., Alfonzo, A., Francesca, N., Corona, O., Di Gerlando, R., Columba, P., et al. (2017). Production of the Sicilian distillate "Spiritu re fascitrari" from honey byproducts: An interesting source of yeast diversity. International Journal of Food Microbiology, 261, 62-72.

Ghaly, A. E., Dave, D., Budge, S., \& Brooks, M. S. (2010). Fish spoilage mechanisms and preservation techniques. American Journal of Applied Science, 7(7), 859.

Gianguzza, A., Pellizzetti, E., \& Sammartano, S. (2002). Chemistry of marine water and sediments. New York: Springer.

Giménez, M. I., Studdert, C. A., Sánchez, J. J., \& De Castro, R. E. (2000). Extracellular protease of Natrialba magadii: Purification and biochemical characterization. Extremophiles, 4(3), 181-188.

Hacisalihoglu, A., Jongejan, J. A., \& Duine, J. A. (1997). Distribution of amines oxidase and amine dehydrogenase in bacteria grown in primary amines and characterization of the amine oxidase from Klebsiella oxytoca. Microbiology, 143, 505-512.

Hall, G. M. (1992). Fish processing technology. London: Blackie Academic \& Professional.

Hernández-Herrero, M. M., Roig-Sagués, A. X., López-Sabater, E. I., RodríguezJerez, J. J., \& Mora-Ventura, M. T. (1999a). Protein hydrolysis and proteinase activity during the ripening of salted anchovy (Engraulis encrasicholus L.). A microassay method for determining the protein hydrolysis. Journal of Agricultural and Food Chemistry, 47(8), 3319-3324.

Hernández-Herrero, M. M., Roig-Sagués, A. X., López-Sabater, E. I., RodriguezJerez, J. J., \& Mora-Ventura, M. T. (1999b). Total volatile basic nitrogen and other physicochemical and microbiological characteristics as related to ripening of salted anchovies. Journal of Food Science, 64(2), 344-347.

Hernandez-Herrero, M. M., Roig-Sagues, A. X., Lopez-Sabater, E. I., RodriguezJerez, J. J., \& Mora-Ventura, M. T. (2002). Influence of raw fish quality on some physicochemical and microbial characteristics as related to ripening of salted anchovies (Engraulis encrasicholus L). Journal of Food Science, 67(7), 2631-2640.

Hernández-Herrero, M. M., Roig-Sagues, A. X., Rodríguez-Jerez, J. J., \& MoraVentura, M. T. (1999c). Halotolerant and halophilic histamine-forming bacteria isolated during the ripening of salted anchovies (Engraulis encrasicholus). Journal of Food Protection, 62(5), 509-514.

Hui, Y. H. (2007). Handbook of food products Manufacturing: Health, meat, milk, poultry, seafood, and vegetables (Vol. 1). Hoboken: Wiley \& Sons.

Hultin, H. O. (1994). Oxidation of lipids in seafoods. In F. Shahidi, \& J. R. Botta (Eds.), Seafoods chemistry, processing technology and quality (pp. 49-74). London: Blackie Academic and Professional.

Izotova, L. S., Strongin, A. Y., Chekulaeva, L. N., Sterkin, V. E., Ostoslavskaya, V. I., Lyublinskaya, L. A., et al. (1983). Purification and properties of serine protease from Halobacterium halobium. Journal of Bacteriology, 155(2), 826-830.

Josephson, D. B. (1991). Seafood. In H. Maarse (Ed.), Volatile compounds in foods and beverages (pp. 179-202). New York: Marcel Dekker Inc.

Kamekura, M., Seno, Y., Holmes, M. L., \& Dyall-Smith, M. L. (1992). Molecular cloning and sequencing of the gene for a halophilic alkaline serine protease (halolysin) from an unidentified halophilic archaea strain (172P1) and expression of the gene in Haloferax volcanii. Journal of Bacteriology, 174(3), 736-742.

Kawashima, M., \& Nishiyama, T. (1989). Salt concentration and chemical types of lake, river, snow and hot spring waters from Tibetan Plateau. Japanese Journal of Limnology, 50(2), 93-104.

Kung, H. F. Lee, Y. C., Tseng, Y. L., Huang, Y. L., Chen, T. Y.. \& Tsai, Y. H. (2016). Degradation of histamine in salted fish product by halotolerant Bacillus Polymyxa. Journal of Food Safety, 36(3), 325-331.

Lee, H. S. (2013). Diversity of halophilic archaea in fermented foods and human intestines and their application. Journal of Microbiology and Biotechnology, 23, $1645-1653$.

Lewis, R. J. Sr (2007). Hawley's condensed chemical dictionary (15th ed.). New York: John Wiley \& Sons Inc.

Macleod, G., \& Ames, J. M. (1986). The effect of heat on beef aroma: Comparisons of chemical composition and sensory properties. Flavour and Fragrance Journal, 1(3), 91-104.

Maffeis, G. (2013). Il miracoloso sale marino: Il rimedio millenario dalle infinite virtù curative. Milano: Riza Editore.

Martuscelli, M., Crudele, M. A., Gardini, F., \& Suzzi, G. (2000). Biogenic amine 
formation and oxidation by Staphylococcus xylosus strains from artisanal fermented sausages. Letters in Applied Microbiology, 31, 228-232.

Moret, S., \& Conte, L. S. (1996). High-performance liquid chromatographic evaluation of biogenic amines in foods an analysis of different methods of sample preparation in relation to food characteristics. Journal of Chromatography A, 729(1), 363-369.

Moschetti, G., Aponte, M., Blaiotta, G., Casaburi, A., Chiurazzi, M., Ventorino, V., et al (2006). Characterization of halophilic Archaea isolated from different hypersaline ecosystems. Annals of Microbiology, 56(2), 119-127.

Oren, A., \& Litchfield, D. C. (1999). A procedure for the enrichment and isolation of Halobacterium. FEMS Microbiology Letters, 173, 353-358.

Pons-Sanchez-Cascado, S., Veciana-Nogués, M. T., Bover-Cid, S., Marine-Font, A., \& Vidal-Carou, M. C. (2005). Volatile and biogenic amines, microbiological counts, and bacterial amino acid decarboxylase activity throughout the salt-ripening process of anchovies (Engraulis encrasicholus). Journal of Food Protection, 68(8), 1683-1689.

Roldan, H. A., Barassi, C. A., \& Trucco, R. E. (1985). Increase on free fatty acids during ripening of anchovies (Engraulis anchoita). International Journal of Food Science and Technology, 20(5), 581-585.

Ryu, K., Kim, J., \& Dordick, J. S. (1994). Catalytic properties and potential of an extracellular protease from an extreme halophile. Enzyme and Microbial Technology, 16(4), 266-275.

Shenderyuk, V. I., \& Bykowski, P. J. (1990). Salting and marinating of fish. In Z. E. Sikorski (Ed.), Seafood: Resources, nutritional composition, and preservation (pp. 147-162). Boca raton: CRC Press Inc.

Shi, W., Tang, X. F., Huang, Y., Gan, F., Tang, B., \& Shen, P. (2006). An extracellular halophilic protease SptA from a halophilic archaeon Natrinema sp. J7: Gene cloning, expression and characterization. Extremophiles, 10(6), 599-606.

Silva, I., Coimbra, M. A., Barros, A. S., Marriott, P. J., \& Rocha, S. M. (2015). Can volatile organic compounds be markers of sea salt? Food Chemistry, 169, 102-113.

Simon Sarkadi, L. (2016). Biogenic amines in fermented foods and health implications. In J. Frias, C. Martinez-Villaluenga, \& E. Peñas (Eds.), Fermented foods in health and disease prevention (pp. 625-651). London Academic press.

Stepanov, V. M., Rudenskaya, G. N., Revina, L. P., Gryaznova, Y. B., Lysogorskaya, E. N.
IYu, F., et al. (1992). A serine proteinase of an archaebacterium, Halobacterium mediterranei. A homologue of eubacterial subtilisins. Biochemical Journal, 285(1), 281-286.

Studdert, C. A., Herrera Seitz, M. K., Plasencia Gil, M. I., Sanchez, J. J., \& de Castro, R. E. (2001). Purification and biochemical characterization of the haloalkaliphilic archaeon Natronococcus occultus extracellular serine protease. Journal of Basic Microbiology, 41(6), 375-383.

Tapingkae, W., Tanasupawat, S., Parkin, K. L., Benjakul, S., \& Visessanguan, W. (2010). Degradation of histamine by extremely halophilic archaea isolated from high salt-fermented fishery products. Enzyme and Microbial Technology, 46(2), $92-99$.

Triqui, R., \& Reineccius, G. A. (1995a). Flavor development in the ripening of anchovy (Engraulis encrasicholus L.). Journal of Agricultural and Food Chemistry, 43(2), 453-458.

Triqui, R., \& Reineccius, G. A. (1995b). Changes in flavor profiles with ripening of anchovy (Engraulis encrasicholus). Journal of Agricultural and Food Chemistry, 43(7), 1883-1889.

Triqui, R., \& Zouine, K. (1999). Sensory and instrumental assessments of the ripening process of anchovy (Engraulis encrasicholus). LWT- Food Science and Technology, 32(4), 203-207.

in't Veld, J. H. H. (1996). Microbial and biochemical spoilage of foods: An overview. International Journal of Food Microbiology, 33(1), 1-18.

Vidyasagar, M., Prakash, S. B., \& Sreeramulu, K. (2006). Optimization of culture conditions for the production of haloalkaliphilic thermostable protease from an extremely halophilic archaeon Halogeometricum sp. TSS101. Letters in Applied Microbiology, 43(4), 385-391.

Villar, M., de Ruiz Holgado, A. P., Sanchez, J. J., Trucco, R. E., \& Oliver, G. (1985) Isolation and characterization of Pediococcus halophilus from salted anchovies (Engraulis anchoita). Applied and Environmental Microbiology, 49(3), 664-666.

Wantke, F., Hemmer, W., Haglmüller, T., Götz, M., \& Jarisch, R. (1996). Histamine in wine. International Archives of Allergy and Immunology, 110(4), 397-400.

Zaman, M. Z., Bakar, F. A., Selamat, J., Bakar, J., Ang, S. S., \& Chong, C. Y. (2014). Degradation of histamine by the halotolerant Staphylococcus carnosus FS19 isolate obtained from fish sauce. Food Control, 40, 58-63. 